\title{
Oligodendrocyte Development and Regenerative Therapeutics in Multiple Sclerosis
}

\author{
Nadjet Gacem *D and Brahim Nait-Oumesmar *(D) \\ Institut du Cerveau—Paris Brain Institute-ICM, Inserm, CNRS, AP-HP, Hôpital de la Pitié Salpêtrière, \\ Sorbonne Université, 75013 Paris, France \\ * Correspondence: nadjet.gacem@icm-institute.org (N.G.); brahim.naitoumesmar@icm-institute.org (B.N.-O.)
}

Citation: Gacem, N.;

Nait-Oumesmar, B. Oligodendrocyte Development and Regenerative Therapeutics in Multiple Sclerosis. Life 2021, 11, 327. https:/ / doi.org/ 10.3390/life11040327

Academic Editor: Nicola Smania

Received: 12 March 2021

Accepted: 7 April 2021

Published: 9 April 2021

Publisher's Note: MDPI stays neutral with regard to jurisdictional claims in published maps and institutional affiliations.

Copyright: (c) 2021 by the authors. Licensee MDPI, Basel, Switzerland. This article is an open access article distributed under the terms and conditions of the Creative Commons Attribution (CC BY) license (https:// creativecommons.org/licenses/by/ $4.0 /)$.

\begin{abstract}
Myelination by oligodendrocytes (OLs) is an important biological process essential for central nervous system (CNS) development and functions. Oligodendroglial lineage cells undergo several morphological and molecular changes at different stages of their lineage progression into myelinating OLs. The transition steps of the oligodendrocyte progenitor cells (OPCs) to myelinating oligodendrocytes are defined by a specific pattern of regulated gene expression, which is under the control of coordinated signaling pathways. Any abnormal development, loss or failure of oligodendrocytes to myelinate axons can lead to several neurodegenerative diseases like multiple sclerosis (MS). MS is characterized by inflammation and demyelination, and current treatments target only the immune component of the disease, but have little impact on remyelination. Recently, several pharmacological compounds enhancing remyelination have been identified and some of them are in clinical trials. Here, we will review the current knowledge on oligodendrocyte differentiation, myelination and remyelination. We will focus on MS as a pathological condition, the most common chronic inflammatory demyelinating disease of the CNS in young adults.
\end{abstract}

Keywords: oligodendrocytes; development; myelination; multiple sclerosis; remyelination

\section{Introduction}

Oligodendrocytes (OLs) are the myelinating cells in the central nervous system (CNS) [1]. They are generated after an orchestrated process of specification (switch of neural progenitors' cells from producing neuronal to glial cells), proliferation, migration and differentiation during brain, optic nerve and spinal cord development [2]. The formation of compact myelin provides insulation for axons and allows the saltatory conduction of action potentials, which is necessary to ensure proper neuronal functions. Furthermore, several studies showed that oligodendrocytes provide to neurons essential metabolic and trophic supports [3-6]. During CNS development, OLs are derived from oligodendrocyte progenitor cells (OPCs). OPCs also persist in the adult CNS, where they represent $5 \%$ to $8 \%$ of total glial cells and are widely distributed in white matter (WM) and to a less extent in grey matter (GM) [7]. This small fraction of adult OPCs remains in a slowly proliferative quiescent state, contributes to myelin remodeling under physiological conditions and to remyelination following a demyelinating injury. Here, we reviewed current knowledge on OPC specification and differentiation into myelinating OLs in physiological conditions and in multiple sclerosis (MS). We also discussed the relevance of these mechanisms for the development of therapeutic approaches for demyelinating diseases.

\section{Oligodendrocyte Development}

\subsection{Emergence and Specification of Oligodendrocyte Progenitor Cells (OPCs)}

Significant progress has been made to discern the signaling pathways implicated in oligodendrocyte specification and differentiation, both in normal and pathological conditions. In the brain, the determination of OPCs from neural progenitors occurs in 
several waves from multiple germinative ventricular zones of the ventral and dorsal forebrain $[8,9]$. During embryonic development of the telencephalon, a first wave of OPCs is generated from Nkx2.1+ (NK2 Homeobox 1) precursor cells in the entopeduncular area (AEP) and the medial ganglionic eminence (MGE) at embryonic day 12.5 (E12.5) [10,11]. This first wave of OPCs is followed by a second wave from Gsh2 (GS homeobox 2)-expressing precursors of the lateral and caudal ganglionic eminences (LGE-CGE) at E15.5. Finally, a third wave of OPCs is generated after birth from Emx1+ (Empty spiracles homeobox 1) precursor cells of the subventricular zones (SVZ) lining the lateral ventricles. Strikingly, the earliest OPCs emerging from the MGE-AEP, are completely eliminated, during postnatal development, in most part of the brain and replaced by the two later waves, except in the ventral forebrain and corpus callosum $[8,9,12]$. Cortical OPCs continue to be generated postnatally from precursor cells located in the SVZ, and migrate radially out of the SVZ to colonize the entire WM and cortex [13-15]. In the spinal cord, OPC specification occurs at around E12.5 in the precursor motoneuron ( $\mathrm{pMN}$ ) domain. These ventrally derived OPCs give rise to $85-90 \%$ of total populating oligodendrocytes. This first wave of OPCs is followed by a second wave from the dorsal ventricular domain $\mathrm{dP} 6$ at E14.5 and contribute to $10-15 \%$ of total myelinating oligodendrocytes [16-18] (Figure 1a).

a

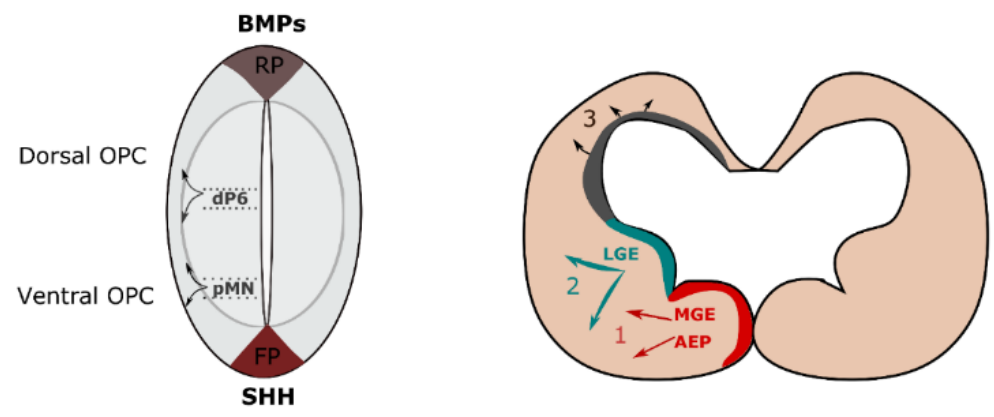

b

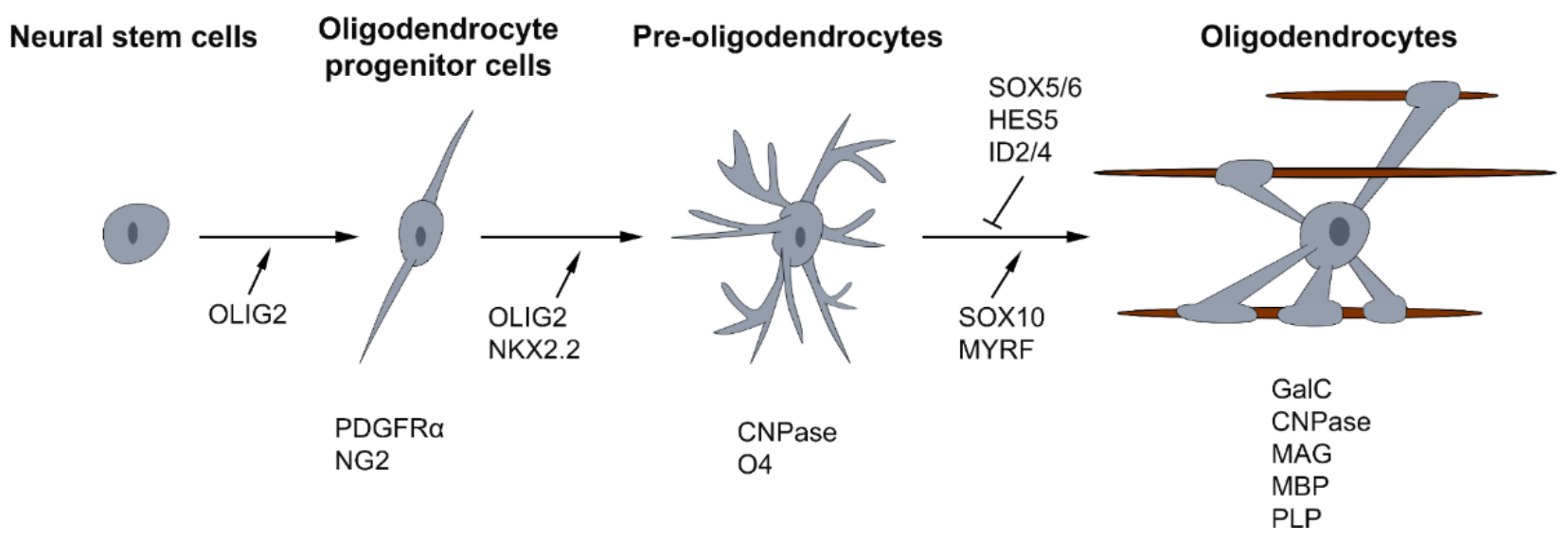

Figure 1. Developmental sources of oligodendrocyte progenitor cells (OPCs) and oligodendroglial cell lineage. (a) Sections of spinal cord and telencephalon showing the successive waves of oligodendrogliogenesis at different developmental stages. (b) Specification and differentiation of neural stem cells into myelinating oligodendrocytes are characterized by distinct stages, which can be identified by the acquisition and/or the disappearance of several specific markers like platelet-derived growth factor receptor (PDGFR)- $\alpha, \mathrm{O} 4$ and proteolipid protein (PLP). The oligodendrocyte lineage progression is under the control of specific transcriptional factors. RP: roof plate, FP: floor plate, AEP: entopeduncular area, MGE: medial ganglionic eminence, LGE: lateral and caudal ganglionic eminences. 
In these different regions, the generation of OPCs is under the control of several intrinsic and extrinsic factors. During development, one of the well-established effectors is the morphogen Sonic Hedgehog (Shh), secreted from the notochord and floor plate, which has been largely implicated in oligodendrogliogenesis in ventral ventricular zones. Shh regulates the expression of key transcription factors implicated in OPC specification including Olig2 and Nkx2.2 [19]. Recently, the use of conditional knockout mice showed also that highly regulated Shh signaling from multiple embryonic sources is required for oligodendrocyte generation from dorsal forebrain progenitors in neocortical regions. For their late embryonic transition to oligodendrogenesis, interneurons migrating into the neocortex and the choroid plexus are important sources of Shh ligand [20]. These studies showed also that some population of dorsal oligodendroglial cells are more affected by the loss of Shh signaling than others [21]. In addition to Shh, fibroblast growth factors (FGFs), bone morphogenetic proteins (BMPs) and Wingless-related integration site (WNTs) provide crucial signaling to form a morphogen gradient along the dorso-ventral axis of the CNS [22].

After their specification, OPCs migrate from their birthplaces to reach their final destinations. Interestingly, several studies showed that distinct OPC populations have the capacity to recover the depletion of oligodendrocytes. For instance in the brain, a specific deletion of dorsally derived OPCs induces a transient reduction in oligodendrocyte number, which is recovered by the expansion of ventrally derived OPCs [8,21]. Moreover, after a specific ablation of ventrally-derived OPCs in the spinal cord, dorsally-derived OPCs are able to undergo a rapid amplification, to colonize the ventral spinal cord and to myelinate axons, although with a temporal delay [23]. These data indicate that ventrallyand dorsally-derived OPC populations have the capacity to compensate the loss of each other, suggesting their functional redundancy.

\subsection{Differentiation of OPCs into Oligodendrocytes}

During development, OPCs undergo morphological and signaling changes to differentiate into myelinating oligodendrocytes. Each step is characterized by the acquisition or/and the disappearance of several specific markers. OPCs express platelet-derived growth factor receptor (PDGFR)- $\alpha$ that stimulates their migration and proliferation and inhibits differentiation. Another marker for OPCs is the proteoglycan NG2. During their transition to pre-oligodendrocytes, OPCs change their morphology and acquire a large cell body and more extended branching. At this stage, they express the cell surface markers $\mathrm{O} 4$ and $2^{\prime}, 3^{\prime}$-cyclic nucleotide $3^{\prime}$-phosphodiesterase (CNPase) [24,25]. Then, pre-oligodendrocytes give rise to differentiated and mature oligodendrocytes that are characterized respectively by the expression of galactocerebroside (GalC)/O1 and myelin proteins, such as the myelin basic protein (MBP), the myelin associated glycoprotein (MAG) and the transmembrane protein proteolipid protein (PLP). The different stages of the oligodendroglial lineage cells and their main markers are illustrated in Figure 1b.

The development of the oligodendroglial lineage cells into myelinating glia is a complex process regulated by several mechanisms and signaling pathways that control a series of transcription factors. For instance, the basic helix-loop-helix (bHLH) transcription factor Olig2 is required for OPC specification during CNS development. Indeed, Olig2 inactivation lead to a depletion of oligodendrocytes [26,27], while Olig2 overexpression promotes the generation of OPCs [28]. The closely related bHLH transcription factor Olig1 has a minor role in OPC commitment and differentiation. In fact, Olig1 null mice show only a slight oligodendrocyte differentiation delay and has no obvious myelination defects [29,30]. Sox10 (Sry-related HMg-Box gene 10) and Nkx2.2, which are induced by Olig2, act in parallel to control oligodendrocyte differentiation and are essentials for myelin gene expression [31]. Sox 10 is a specific marker of oligodendrocyte lineage in the CNS and is a key regulator of oligodendrocyte differentiation and myelination by regulating several genes implicated directly in this process, including the transcription factor Myrf (myelin regulatory factor) [32,33]. Another HMG-box transcription factor, Sox17, was 
identified as a positive or negative regulator of oligodendrocyte development, depending on the oligodendroglial cell stage. Sox17 over-expression increase the pool of OPCs during early postnatal development and acts as a negative regulator of OPC differentiation and myelination [34]. While, inactivation of Sox17 reduces the number of Olig2 positive cells and, as a consequence, the number of mature oligodendrocytes [35]. Moreover, Sox5 and Sox6 regulate oligodendrocyte development in the mouse spinal cord. These group D of Sox transcription factors inhibits OPC specification and terminal differentiation [36]. Hes1/5 and Id2/4 were also identified to maintain cells at the OPC stage and inhibits their differentiation $[37,38]$. Nuclear receptors form another class of transcription factors implicated in oligodendrocyte lineage development and differentiation, and act through dimerization. This family of transcription factors include LXR (liver X receptors), RXR (retinoid $\mathrm{X}$ receptors), PPAR (peroxisome proliferator-activated receptors), vitamin D receptors, and THR (thyroid hormone receptors). They are activated through homodimerization or dimerization and can bind to their co-repressors or co-activators. Several studies demonstrated that these nuclear receptors are important for the transcriptional control of myelin gene expression and play key roles in oligodendrocyte differentiation and myelination processes. For example, knocked out mice for LXRs exhibited thinner myelin sheaths and reduced myelin gene expression [39]. The main function of LXRs is to coordinate lipid metabolism, essential for the myelin production by oligodendrocytes. Moreover, deficient mice for RXR- $\gamma$ showed delayed differentiation into mature oligodendrocytes [40]. It was also reported that the vitamin D receptor forms a heterodimer with RXR and induces OPC differentiation [41].

Axonal signals, among which action potentials, also regulate the lineage progression from OPCs to myelinating oligodendrocytes. Indeed, compelling evidence indicates that oligodendroglia cells are able to sense neuronal activity $[42,43]$ and preferentially myelinate electrically active axons. Action potentials along axons trigger neurotransmitter vesicular release that is a key modulator of the myelination process [44-46]. Interestingly, OPCs are also synaptically innervated by glutamatergic and GABAergic neuronal fibers throughout the CNS [47,48]. These synaptic communications between axons and OPCs may constitute a possible mechanism to control oligodendrocyte development in an activity-dependent manner. However, the functional role of these synaptic connections in myelination has not yet been clearly established in vivo.

\subsection{Regulation of Central Nervous System (CNS) Myelination}

The maturation of oligodendrocytes into myelinating cells pass through different morphological changes and is characterized by expression of oligodendrocyte-specific proteins and lipids. When oligodendrocytes start to mature, they produce a multilayered myelin sheath [49]. Myelin contains $70-80 \%$ of lipids and around $30 \%$ of proteins, among which MBP and PLP are the most abundant. An oligodendrocyte myelinates several internodes located on different nerve fibers in the CNS and that terminate at paranodal loops bordering the nodes of Ranvier [50]. In addition to the main transcription factors listed above, several others have been implicated in the myelination process. These proteins are regulating gene expression and act directly by stimulating several genes controlling myelination, such as Olig2, Sox10, Yy1 (Yin and Yang 1), Nxk2.2 and Myrf, or indirectly by repressing repressors of myelination [51]. The signaling pathways regulating myelination include the phosphoinositide 3-kinase (PI3-kinases)/Akt/ mammalian target of rapamycin (mTOR) and extracellular signal-regulated kinases (ERK)-1/2 pathways, which have a fundamental role in oligodendrocyte development, myelination, and remyelination [52-55]. The Wnt pathway has been also well characterized and is largely implicated in oligodendrocyte development. Studies suggest that $\mathrm{Wnt} / \beta$-catenin pathway activation impaired myelination [56].

Axons express also on their surface inhibitors and molecules permissive of myelination. This mechanism controls the need or not of myelination, to ensure correct neuronal functions. Interestingly, most of these molecules are identified as inhibitors of myelination. These inhibitory axonal signals such us Jagged (acting via Notch signaling), PSA-NCAM, 
and LINGO-1, activate various transcriptional regulators such as Hes5, Sox 5/6, and Id2/4, and therefore prevent OPC differentiation into myelinating oligodendrocytes $[57,58]$. Other transcription factors, such as sterol regulatory element binding proteins (SREBPs), regulate the expression of genes involved in lipid synthesis, which is crucial for a proper myelination. Indeed, recent studies suggest that a substantial fraction of the lipids incorporated during myelin formation is from astrocytes in the normal brain. Lipid metabolism via SREBPs signaling in astrocyte supply myelin formation in oligodendrocytes through transcellular transport. SREBPs expression and lipid metabolism and storage are controlled by the mTOR pathway, which is also essential for myelination $[59,60]$.

Myelination occurs also in the adult CNS in response to neuronal activity or environmental cues [61,62], and contributes to the slow turnover of the myelin sheaths caused by the loss and dysregulation of OLs occurring during aging [63]. For that, OPCs persist in the adult and tend to homeostatically maintain their cell number [64]. Cell fate mapping [65] and transplantation experiments of adult OPCs [66], as well as RNAseq studies clearly demonstrated that the myelinating capacity of adult OPCs are not similar in all regions $[67,68]$. For instance, adult OPCs in the CNS white matter have higher proliferation and differentiation rate into myelinating oligodendrocytes than those located in the gray matter, where they remain mainly undifferentiated under physiological conditions.

Spontaneous remyelination of demyelinated axons is an important mechanism that occurs in pathological conditions. The different steps of the remyelination process include OPC activation/proliferation, their migration towards the demyelinated area and finally their differentiation into myelinating oligodendrocytes [69]. These steps are highly regulated by several mechanisms that recapitulate partially those involved during developmental myelination, such as nuclear receptors and their ligands (LXRs $\alpha / \beta, \operatorname{PPAR} \gamma$, Vitamin D receptor and RXRs), which are important for remyelination [39-41,70]. Moreover, transcription factors like Myrf, Olig1, Ascl1 and Olig2 that regulate developmental myelination also promote remyelination. For instance, Ascl1 expression increases during remyelination and is required for the proper timing of OPCs differentiation in demyelinated lesions [71]. Olig2 overexpression enhance OPC differentiation and accelerate remyelination [72]. Moreover, in mice lacking Olig1, oligodendrocytes fail to remyelinate and confirm the implication of this factor for efficient remyelination in the brain [73].

Recent single cell RNAseq data indicate that OPCs and oligodendrocytes are heterogeneous, suggesting presumably distinct functional states. For instance, single-cell RNAseq performed on oligodendroglial cells during mouse brain development as well as in the adult, revealed six sub-populations of myelinating oligodendrocytes that are transcriptionally distinct, suggesting that oligodendrocytes are functionally heterogeneous in different CNS regions [74]. Intriguingly, this heterogeneity is also found in the adult mouse CNS following demyelination and in MS lesions [75] (see next chapter). In the experimental encephalomyelitis mouse model of demyelinating, scRNAseq experiments showed that oligodendroglial cells can express immune specific genes such as MHCI and MHCII and that OPCs can have phagocytic and antigen presenting functions [75]. These data highlight unexpected immunomodulatory functions of oligodendroglial cells, which are commonly attributed to macrophages/microglia. Importantly, oligodendroglia heterogeneity is also seen in MS brain tissue, both in lesions and normal appearing white matter, with seven sub-clusters of OLs, some of which showed similarities with those described in the mouse CNS [76]. Single nuclear RNAseq of oligodendroglial cells in MS lesions also revealed that mature OLs upregulate myelin gene transcripts, arguing that mature OLs, rather OPCs, could contribute to remyelination in the human brain, as also pointed by recent findings using retrospective carbon 14 cell fate mapping [77]. These recent studies also challenge our current view indicating that OPCs are the main contributing cell type to remyelination and suggest instead that these cells could contribute to autoimmune-mediated demyelination in the human brain [78].

In several neurodegenerative diseases, CNS myelin can be damaged and in some cases the capacity of OL regeneration and remyelination are affected $[79,80]$. In the next 
chapter, we focused on MS, the most common chronic inflammatory demyelinating of the CNS in young adults. Different in vitro and in vivo experimental models have been used to understand the pathophysiology of this disease, in particular oligodendrocyte differentiation and remyelination failure that contribute to MS progression.

\section{Toward Remyelination and Repair in Multiple Sclerosis (MS)}

\subsection{MS: Clinical Forms and Pathological Features of the Lesions}

MS is the most frequent chronic inflammatory disease associated with CNS demyelination. There are more than 2 million people affected in the world. MS is most prevalent in Europe, North America and Australia while it is lower in Asia and Africa, and usually begins in early adulthood. This autoimmune disease is characterized by diffuse inflammatory demyelinated lesions in several CNS region including white and gray matter, brain stem, spinal cord and optic nerve [81]. Four main clinical forms have been described in MS. The most common one is the relapsing-remitting form (RRMS) affecting about $80 \%$ of MS patients, and which is characterized by symptoms over a period of several days followed by stabilization and then complete or partial recovery. Persistent signs after several years can increase and RRMS may progress between relapses to a secondary progressive MS form (SPMS). The other group of affected patients ( $20 \%$ ) develops, from the onset of the disease, gradually progressive and severe clinical symptoms (primary progressive MS, PPMS). The overlap of PPMS and SPMS represents clinical symptoms of progressive relapsing MS (PRMS). Patients of this group present a progressive worsening of the condition from the beginning, similar to PPMS, accompanied with occasional relapse episodes of intensified clinical symptoms similar to those observed in relapsing-remitting MS (RRMS).

Several types of disseminated MS lesions have been characterized and classified according to the presence or absence of inflammatory cells, composed mainly of macrophages and microglia. In active demyelinating lesions, a dense infiltration of macrophages that phagocytes myelin products is observed. Chronic active and smoldering MS lesions (mixed active/inactive lesions) are characterized by the presence of activated macrophage/microglia within or surrounding demyelinated lesions, respectively, and myelin degradation products in phagocytes [82]. Only few macrophages/microglia cells are found, in the center of chronic active of demyelinated lesions. Chronic active lesions are characterized by a hypocellularity in the lesion core and may show thin myelin sheaths at the edge, representing remyelination. Inactive lesions are hypocellular in the lesion area with a drastic reduction of macrophages/microglia cells compared to the other types of MS lesion, and almost completely depleted of mature oligodendrocytes [83]. Shadow plaques are sharply demarcated plaques in a typical MS distribution, associated with only a modest decrease of axonal density. Shadow plaques represent complete remyelination of previously demyelinated plaques with disproportionately thin myelin sheaths and the presence of few macrophages. Demyelination may be associated with the loss of oligodendrocytes, and block of OPC differentiation to mature oligodendrocytes [84]. In this case, remyelination is insufficient, and chronic demyelination contributes to axonal loss, which lead to progressive and irreversible neurological disability.

Heterogeneity of MS lesions, as well as the unknown etiology and events that initiate this disease complicate the generalization of therapy in all MS patients. Two pathological hypothesis, which could trigger CNS demyelination, were proposed by the scientific community. The first one is called "outside-in". In this case, immune cells of peripheral adaptive immune system migrate across the blood brain barrier enter and attack the CNS after their activation, expansion and secretion of pro-inflammatory cytokines. This inflammation state stimulates microglia and astrocytes and recruits other immune cells that amplify inflammatory response and induce the destruction of myelin, oligodendrocytes and axons. The "inside-out" mechanism suggests that this attack starts inside the CNS. Degeneration of oligodendrocytes and myelin is the initial event, and after oligodendrocyte death and myelin degradation, a secondary autoimmune attack is initiated, resulting in inflammatory demyelination [85]. 


\subsection{Therapeutic Approaches in MS}

\subsubsection{Immunomodulatory Therapy}

Currently, all treatments approved for MS therapy aim to modulate the immune response with immunomodulatory and/or immunosuppressive drugs. These therapeutic strategies are frequently used to treat clinically significant relapses. All these diseasemodifying therapies are used to modulate or suppress inflammation. Several drugs have been tested so far in clinical practice, some of which can reduce relapses and symptoms in MS patients. More than 20 drugs approved by the Food and Drug Administration (FDA) are used for RRMS, and some of them are used in the secondary progressive forms of MS, when still associated with relapsing-remitting phases. This list of FDA approved drugs includes interferon $\beta-1 \mathrm{a} / 1 \mathrm{~b}$, mitotranxone, glatiramer acetate, dimethyl fumarate, teriflunomide, fingolimod, siponimod, cladribine, ocrelizumab, ofatumumab, alemtuzumab, daclizumab, natalizumab and ozanimob [86].

\subsubsection{Remyelination Therapies}

Most of the current immunomodulatory therapies used in MS fail to prevent or reverse progressive forms of the disease. This support the notion that persistent demyelination may, in some types of lesion, be the major cause of neurological disability in patients. The current challenge in MS, in addition to therapies targeting inflammation, is to promote remyelination in order to prevent axonal degeneration and, therefore, accumulation of neurological disability. Several promising ongoing research strategies for drug discovery of pharmacological compounds target OPC differentiation with the ultimate goal to find new treatments for progressive MS. Although, it is worth noting that human oligodendrocytes, derived from IPSCs of MS patients, have normal myelination properties and interact with axons when grafted in the shiverer:rag2 mouse brain [87], suggesting that the oligodendrocyte differentiation block is not related to an intrinsic defect of this cell type.

The development of remyelination therapies in patients with MS requires profound knowledge of the cellular and molecular mechanisms regulating myelination, in order to find potential pharmacological targets modulating this process, which could be tested under demyelinating conditions (hypothesis-driven approach). The other approach is to perform a large screen of chemical libraries with the goal to find drugs enhancing OPC differentiation and remyelination, using for example primary rat OPCs culture and/or organotypic cerebellar slice cultures (Figure 2). The development of new drugs stimulating oligodendrocyte's maturation and myelination represent a promising approach, which can be used alone or in combination with immunomodulatory therapy.

Several compounds favoring remyelination and targeting several signaling pathways have been identified in the last decade. In 2013, Deshmukh et al. [88] performed a high content screening for MBP expression using primary rat OPCs and identified benztropine among the most effective compounds. Benztropine acts as an anti-muscarinic receptor M1/M3 and is a FDA approved treatment for Parkinson's disease. This compound increases MBP expression in rat primary OPCs derived from optic nerves, induce remyelination and decrease significantly clinical symptoms in the experimental autoimmune encephalomyelitis (EAE) model of MS, when administered alone or in combination with approved immunosuppressive treatments for MS, interferon $-\beta$ and FTY720. Benztropine enhances OPC differentiation and remyelination in vivo in the cuprizone-induced model of demyelination. Clemastine, another anti-muscarinic was identified among a cluster of antimuscarinic compounds including benztropine, quetiapine and others, using a micropillar array high throughput screening for OPC differentiation and myelination. Clemastine and benzatropine are FDA-approved compounds that cross the blood-brain barrier. They were also the most effective drugs in enhancing oligodendrocyte differentiation and myelination, using purified oligodendroglia cultured alone or with purified DRG neurons. Clemastine enhances and accelerates the kinetics of remyelination in mice after lysolecithin-induced demyelination [89]. M1 muscarinic acetylcholine receptor was identified as a target for remyelination and its oligodendroglial-specific genetic ablation accelerates remyelination 
and prevents axonal loss in mouse EAE [90]. In addition, clemastine rescues behavioral changes by enhancing remyelination in the cortex and corpus callosum in the cuprizone model of demyelination [91], and in the prefrontal cortex of adult mice following social isolation [92]. Altogether, these findings demonstrate that enhancing remyelination supports axonal integrity and neuronal function in several experimental models of MS.

a


b

\section{SOX10/CaBP/MBP}

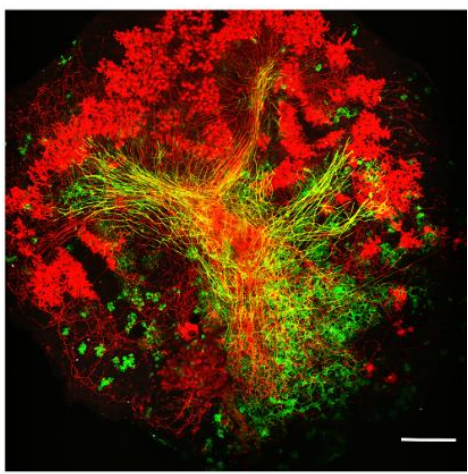

Figure 2. In vitro and ex-vivo models used in screening and validation assays of compounds affecting myelination. (a) Oligodendrocyte differentiation in primary rat OPCs culture. OPCs cells are obtained from $\mathrm{P} 1$ neonatal rat cortices and differentiated 5 days in vitro into mature oligodendrocytes expressing Sry-related HMg-Box gene 10 (Sox10, white), 2' , 3'-cyclic nucleotide $3^{\prime}$-phosphodiesterase (CNPase, red) and myelin basic protein (MBP, green). Nuclei are counterstained with $4^{\prime}, 6$-diamidino2-phénylindole (Dapi) (bleu). (b) Organotypic cerebellar slices maintained in culture for 10 days to visualize ex-vivo myelination. Sox10 was used to stain oligodendroglia (white), MBP for myelin (green) and calbindin (CaBp) for Purkinje cells (red). Scale bars (a: $80 \mu \mathrm{m}, \mathrm{b}: 160 \mu \mathrm{m})$.

In addition to muscarinic receptors, LINGO-1 is expressed by oligodendrocytes and acts as a potent negative regulator of OLs differentiation and myelination. Loss of LINGO-1 function using LINGO-1 RNA-mediated interference (RNAi), dominant negative LINGO-1, or soluble human LINGO-1 (LINGO-1-Fc) decreases RhoA activity, which has been implicated in OLs differentiation and axonal myelination [93]. Opicinumab (BIIB033), has been recently developed, as a CNS-specific membrane glycoprotein that acts as a LINGO-1 blocker. The targeted inhibition of LINGO-1 acts by blocking molecules such as Nogo-A and RhoA, and consequently promote remyelination and axonal protection $[94,95]$. In a randomized, doubleblind and placebo-controlled, dose-ranging phase II study (SYNERGY) (NCT01864148), opicinumab was used in combination with intramuscular Interferon-beta (IFN $\beta$ )-1a therapy. The results did not show a significant dose-linear improvement in disability, but some subpopulation identified in the study seems to respond most to opicinumab therapy [96]. To further support these data, the phase 2 AFFINITY study (NCT03222973) of opicinumab, as an add-on to multiple anti-inflammatory disease-modifying treatments, has been initiated to assess the efficacy and safety of this drug in a targeted population of patients with relapsing MS identified from the SYNERGY study.

GSK239512 and GSK247246 are histamine H3 receptor (H3R) antagonists that have been developed for the treatment of Alzheimer's disease and schizophrenia [97]. GSK247246 was identified as a potential remyelinating compound after the screening of 1000 compounds on rat OPC cultures. This compound enhances remyelination in the corpus callosum and cortex in the cuprizone model of demyelination model [98]. In a phase II, clinical trial as an add-on to a preexisting disease-modifying therapy with intramuscular interferon- $\beta 1$ a or glatiramer acetate including 131 patients (NCT01772199), treatment with GSK239512 shows a small positive effect on remyelination compared to placebo treatment, although some adverse events like insomnia were more common with in participants treated with GSK239512 [99]. 
Najm et al. [100], using a high-content imaging phenotypic screening, identified miconazole and clobetasol that act on OPCs through mitogen-activated protein kinase (MAPK) and glucocorticoid receptor (GR) signaling, respectively. These two drugs promote myelination in several in vitro and in vivo models and enhance the generation of oligodendrocytes from human OPCs in vitro. Later, the same group showed that a group of pro-myelinating small molecules, identified in the first study, inhibits CYP51 (cytochrome P450, family 51), TM7SF2 ((Transmembrane 7 Superfamily Member 2), or EBP (emopamil binding protein) and induces accumulation of 8,9-unsaturated sterols that drive oligodendrocyte differentiation and remyelination [101]. Clobetasol and halcinonide have also been shown to act as a smoothened agonist and activate retinoid $X$ receptor $\gamma(R X R \gamma)$ [102]. The use of mixed embryonic cortical cell cultures containing both OPCs and axons was used also to screen a FDA-approved library of 727 compounds and select 27 hit compounds promoting myelination $[103,104]$. These compounds were grouped according to their mechanism of action, such as muscarinic receptor antagonists, selective estrogen receptor modulators or adrenergic agonists.

The number of myelinating compounds identified and tested in pre-clinical or clinical trials has significantly increased over the past 5 years with a deeper understanding of the mechanisms regulating the development of oligodendrocytes and the myelination process. The variety of screening strategies using various in vitro culture systems and rodent models of MS allowed the most efficient drugs to be selected for further clinical trials (Table 1). However so far, none of the listed drugs have reached clinical use in MS. The discovery and development of new promyelinating drugs is still a major unmet medical need to prevent disease progression in MS.

Table 1. Clinical trials results related to remyelination.

\begin{tabular}{|c|c|c|c|c|}
\hline Drugs & Mechanism of Action & Clinical Trial & $\begin{array}{c}\text { Efficacity in Clinical } \\
\text { Trial }\end{array}$ & $\begin{array}{l}\text { ClinicalTrials.gov } \\
\text { Identifier }\end{array}$ \\
\hline Biotin or MD1003 & $\begin{array}{l}\text { Cofactor for } \\
\text { carboxylases involved } \\
\text { in fatty acid synthesis }\end{array}$ & $\begin{array}{l}\text { Phase III: patients suffering } \\
\text { from progressive MS }\end{array}$ & $\begin{array}{l}\text { MD1003 cannot be } \\
\text { recommended for PMS }\end{array}$ & $\begin{array}{l}\text { NCT02936037 } \\
\text { NCT03215433 } \\
\text { NCT03302806 } \\
\text { NCT03552211 }\end{array}$ \\
\hline $\begin{array}{l}\text { Adrenocorticotropic } \\
\text { hormone (ACTH) }\end{array}$ & $\begin{array}{l}\text { Polypeptide tropic } \\
\text { hormone }\end{array}$ & $\begin{array}{l}\text { Phase IV: patients with } \\
\text { RRMS or SPMS with new } \\
\text { contrast-enhancing lesions }\end{array}$ & Ongoing & NCT02446886 \\
\hline Bazedoxifene Acetate & $\begin{array}{l}\text { Selective estrogen } \\
\text { receptor modulator }\end{array}$ & $\begin{array}{l}\text { Phase II: patients with } \\
\text { RRMS }\end{array}$ & Ongoing & NCT04002934 \\
\hline BIIB061 & Anti-tau $\mathrm{mAb}$ & Phase II: patients with RMS & Ongoing & NCT04079088 \\
\hline Clemastine & $\begin{array}{l}\text { Antimuscarinic/ } \\
\text { antihistamine }\end{array}$ & $\begin{array}{l}3 \text { Phase II: patients with } \\
\text { acute optic } \\
\text { neuritis/patients with } \\
\text { relapsing forms of MS }\end{array}$ & $\begin{array}{l}\text { Reduced latency delay } \\
\text { of VEPs }\end{array}$ & $\begin{array}{l}\text { NCT03109288 } \\
\text { NCT02521311 } \\
\text { NCT02040298 }\end{array}$ \\
\hline Nanocrystalline gold & $\begin{array}{l}\text { Increase levels of the } \\
\text { NAD+, intracellular } \\
\text { ATP levels and } \\
\text { extracellular lactate } \\
\text { levels }\end{array}$ & $\begin{array}{l}\text { Phase II: patients with } \\
\text { chronic vision impairment } \\
\text { as a result of RRMS }\end{array}$ & Ongoing & NCT03536559 \\
\hline Domperidone & Dopamine antagonist & $\begin{array}{l}2 \text { Phase II: RRMS patients } \\
\text { who are being treated with } \\
\text { standard DMT and have } \\
\text { new lesions/SPMS }\end{array}$ & No results posted & $\begin{array}{l}\text { NCT02493049 } \\
\text { NCT02308137 }\end{array}$ \\
\hline RHIgM22 & $\begin{array}{l}\text { Remyelinating } \\
\text { monoclonal antibody }\end{array}$ & $\begin{array}{c}2 \text { Phase I: RMS } \\
\text { subjects/patients with all } \\
\text { clinical presentations of MS }\end{array}$ & No results posted & $\begin{array}{l}\text { NCT02398461 } \\
\text { NCT01803867 }\end{array}$ \\
\hline
\end{tabular}


Table 1. Cont

\begin{tabular}{|c|c|c|c|c|}
\hline Drugs & Mechanism of Action & Clinical Trial & $\begin{array}{c}\text { Efficacity in Clinical } \\
\text { Trial }\end{array}$ & $\begin{array}{c}\text { ClinicalTrials.gov } \\
\text { Identifier }\end{array}$ \\
\hline Thyroid hormone & $\begin{array}{l}\text { Heterodimers with } \\
\text { retinoid X receptors }\end{array}$ & $\begin{array}{c}\text { Phase I: subjects with } \\
\text { MS }\end{array}$ & $\begin{array}{c}\text { Short-term safety and } \\
\text { tolerability in people } \\
\text { with MS }\end{array}$ & $\begin{array}{l}\text { NCT02760056 } \\
\text { NCT02506751 }\end{array}$ \\
\hline Opicinumab (BIIB033) & Anti-LINGO-1 mAb & $\begin{array}{c}4 \text { phase II trials: } \\
\text { unilateral acute optic } \\
\text { neuritis/active RMS } \\
\text { used with Avonex }\end{array}$ & $\begin{array}{c}\text { No effect on } \\
\text { remyelination (ITT } \\
\text { population)/ongoing }\end{array}$ & $\begin{array}{l}\text { NCT01721161 } \\
\text { NCT02657915 } \\
\text { NCT01864148 } \\
\text { NCT03222973 }\end{array}$ \\
\hline GSK239512 & $\begin{array}{c}\text { Histamine } \mathrm{H}_{3} \text { receptor } \\
\text { antago- } \\
\text { nist/antimuscarinic }\end{array}$ & $\begin{array}{l}\text { Phase II: subjects with } \\
\text { RRMS, receiving } \\
\text { intramuscular } \\
\text { interferon- } \beta 1 \mathrm{a} \text { or } \\
\text { glatiramer acetate }\end{array}$ & $\begin{array}{l}\text { Positive effect sizes in } \\
\text { MTR for GdE and } \\
\text { Delta-MTR lesions }\end{array}$ & NCT01772199 \\
\hline Quetiapine & $\begin{array}{c}\text { Dopamine type } 2 \text { and } \\
\text { serotonin } 2 \mathrm{~A}(5 \mathrm{HT} 2 \mathrm{~A}) \\
\text { receptors antago- } \\
\text { nist/antimuscarinic }\end{array}$ & $\begin{array}{l}\text { Phase I/II: subjects } \\
\text { with RRMS }\end{array}$ & No results posted & NCT02087631 \\
\hline VX15/2503 & $\begin{array}{c}\text { Inhibition of } \\
\text { semaphorin } 4 \mathrm{D}\end{array}$ & Phase I & Safe and well tolerated & NCT01764737 \\
\hline Testosterone & $\begin{array}{l}\text { Binding to and } \\
\text { activation of the } \\
\text { androgen receptor }\end{array}$ & $\begin{array}{c}\text { Phase II: patients with } \\
\text { RRMS }\end{array}$ & Ongoing & NCT03910738 \\
\hline Olesoxime & $\begin{array}{l}\text { Cholesterol-like } \\
\text { neuroprotective } \\
\text { compound }\end{array}$ & $\begin{array}{l}\text { Phase I: patients with } \\
\text { stable RRMS, on top of } \\
\text { Interferon beta }\end{array}$ & No results posted & NCT01808885 \\
\hline
\end{tabular}

VEP: Visual Evoked Potential; MTR: Magnetization Transfer Ratio; DMT: Disease-Modifying Treatment; GdE: Gadolinium-enhanced; mAb: Monoclonal Antibody; NAD: Nicotinamide Adenine Dinucleotide; ATP: Adenosine Triphosphate; MS: Multiple Sclerosis; RRMS: Relapsing-Remitting Multiple Sclerosis; SPMS: Secondary Progressive Multiple Sclerosis; PMS: Progressive Multiple Sclerosis; RMS: Relapsing Multiple Sclerosis; ITT: intention-to-treat.

\section{Conclusions}

Deciphering mechanisms implicated in OL differentiation, myelination and remyelination is a major advance to understand their implication in neurodegenerative diseases. The use of different in vitro and in vivo physiopathological models aims to better understand regulation and deregulation of this major glial cell type, with the aim to identify the best therapeutic targets for OL regeneration and remyelination. In MS, OLs are the main actors and are essential to effectively remyelinate lesions in patients. In addition to immune-based strategy, the investigation of potential promyelinating agents is currently the aim of several promising ongoing studies. The combination of these two strategies to modulate the immune response and improve myelin repair in patients with MS could be complementary for the development of effective regenerative therapies.

Author Contributions: N.G. designed the figures, wrote and edited the manuscript. B.N.-O. wrote and edited the manuscript. All authors have read and agreed to the published version of the manuscript.

Funding: This work was supported by the Progressive MS Alliance (collaborative research network PA-1604-08492 (BRAVEinMS) to B.N.-O.), the Investissements d'Avenir ANR-10-IAIHU-06 (IHUA-ICM) and ANR-11-INBS-0011 (NeurATRIS) (to B.N.-O.), and the Fondation Marie-Ange Bouvet Labruyère (to N.G.).

Institutional Review Board Statement: Not applicable.

Informed Consent Statement: Not applicable.

Data Availability Statement: Not applicable. 
Acknowledgments: The fluorescence imaging (Figure 2) was performed at the Paris Brain Institute (ICM) Cell Culture Facility (CELIS), which we thank for their helpful advice and technical assistance.

Conflicts of Interest: The authors declare no conflict of interest.

\section{References}

1. Bunge, R.P. Glial cells and the central myelin sheath. Physiol. Rev. 1968, 48, 197-251. [CrossRef]

2. Bradl, M.; Lassmann, H. Oligodendrocytes: Biology and pathology. Acta Neuropathol. 2010, 119, 37-53. [CrossRef]

3. Garbern, J.Y.; Yool, D.A.; Moore, G.J.; Wilds, I.B.; Faulk, M.W.; Klugmann, M.; Nave, K.A.; Sistermans, E.A.; van der Knaap, M.S.; Bird, T.D.; et al. Patients lacking the major CNS myelin protein, proteolipid protein 1, develop length-dependent axonal degeneration in the absence of demyelination and inflammation. Brain 2002, 125, 551-561. [CrossRef]

4. $\quad$ Funfschilling, U.; Supplie, L.M.; Mahad, D.; Boretius, S.; Saab, A.S.; Edgar, J.; Brinkmann, B.G.; Kassmann, C.M.; Tzvetanova, I.D.; Mobius, W.; et al. Glycolytic oligodendrocytes maintain myelin and long-term axonal integrity. Nature 2012, 485, 517-521. [CrossRef]

5. Nave, K.A.; Werner, H.B. Myelination of the nervous system: Mechanisms and functions. Annu. Rev. Cell Dev. Biol. 2014, 30, 503-533. [CrossRef]

6. Duncan, G.J.; Manesh, S.B.; Hilton, B.J.; Assinck, P.; Plemel, J.R.; Tetzlaff, W. The fate and function of oligodendrocyte progenitor cells after traumatic spinal cord injury. Glia 2020, 68, 227-245. [CrossRef]

7. Dawson, M.R.; Polito, A.; Levine, J.M.; Reynolds, R. NG2-expressing glial progenitor cells: An abundant and widespread population of cycling cells in the adult rat CNS. Mol. Cell Neurosci. 2003, 24, 476-488. [CrossRef]

8. Kessaris, N.; Fogarty, M.; Iannarelli, P.; Grist, M.; Wegner, M.; Richardson, W.D. Competing waves of oligodendrocytes in the forebrain and postnatal elimination of an embryonic lineage. Nat. Neurosci. 2006, 9, 173-179. [CrossRef] [PubMed]

9. Richardson, W.D.; Kessaris, N.; Pringle, N. Oligodendrocyte wars. Nat. Rev. Neurosci. 2006, 7, 11-18. [CrossRef] [PubMed]

10. Spassky, N.; Heydon, K.; Mangatal, A.; Jankovski, A.; Olivier, C.; Queraud-Lesaux, F.; Goujet-Zalc, C.; Thomas, J.L.; Zalc, B. Sonic hedgehog-dependent emergence of oligodendrocytes in the telencephalon: Evidence for a source of oligodendrocytes in the olfactory bulb that is independent of PDGFRalpha signaling. Development 2001, 128, 4993-5004. [PubMed]

11. Tekki-Kessaris, N.; Woodruff, R.; Hall, A.C.; Gaffield, W.; Kimura, S.; Stiles, C.D.; Rowitch, D.H.; Richardson, W.D. Hedgehogdependent oligodendrocyte lineage specification in the telencephalon. Development 2001, 128, 2545-2554.

12. Rowitch, D.H.; Kriegstein, A.R. Developmental genetics of vertebrate glial-cell specification. Nature 2010, 468, 214-222. [CrossRef]

13. Luskin, M.B. Neuroblasts of the postnatal mammalian forebrain: Their phenotype and fate. J. Neurobiol. 1998, 36, 221-233. [CrossRef]

14. Spassky, N.; Goujet-Zalc, C.; Parmantier, E.; Olivier, C.; Martinez, S.; Ivanova, A.; Ikenaka, K.; Macklin, W.; Cerruti, I.; Zalc, B.; et al. Multiple restricted origin of oligodendrocytes. J. Neurosci. 1998, 18, 8331-8343. [CrossRef]

15. Fancy, S.P.; Chan, J.R.; Baranzini, S.E.; Franklin, R.J.; Rowitch, D.H. Myelin regeneration: A recapitulation of development? Annu. Rev. Neurosci. 2011, 34, 21-43. [CrossRef] [PubMed]

16. Cai, J.; Qi, Y.; Hu, X.; Tan, M.; Liu, Z.; Zhang, J.; Li, Q.; Sander, M.; Qiu, M. Generation of oligodendrocyte precursor cells from mouse dorsal spinal cord independent of Nkx6 regulation and Shh signaling. Neuron 2005, 45, 41-53. [CrossRef] [PubMed]

17. Fogarty, M.; Richardson, W.D.; Kessaris, N. A subset of oligodendrocytes generated from radial glia in the dorsal spinal cord. Development 2005, 132, 1951-1959. [CrossRef] [PubMed]

18. Tripathi, R.B.; Clarke, L.E.; Burzomato, V.; Kessaris, N.; Anderson, P.N.; Attwell, D.; Richardson, W.D. Dorsally and ventrally derived oligodendrocytes have similar electrical properties but myelinate preferred tracts. J. Neurosci. 2011, 31, 6809-6819. [CrossRef]

19. Jessell, T.M. Neuronal specification in the spinal cord: Inductive signals and transcriptional codes. Nat. Rev. Genet. 2000, 1, 20-29. [CrossRef]

20. Winkler, C.C.; Yabut, O.R.; Fregoso, S.P.; Gomez, H.G.; Dwyer, B.E.; Pleasure, S.J.; Franco, S.J. The Dorsal Wave of Neocortical Oligodendrogenesis Begins Embryonically and Requires Multiple Sources of Sonic Hedgehog. J. Neurosci. 2018, 38, 5237-5250. [CrossRef]

21. Winkler, C.C.; Franco, S.J. Loss of Shh signaling in the neocortex reveals heterogeneous cell recovery responses from distinct oligodendrocyte populations. Dev. Biol. 2019, 452, 55-65. [CrossRef] [PubMed]

22. Ulloa, F.; Briscoe, J. Morphogens and the control of cell proliferation and patterning in the spinal cord. Cell Cycle 2007, 6, 2640-2649. [CrossRef]

23. Fang, M.; Yu, Q.; Ou, B.; Huang, H.; Yi, M.; Xie, B.; Yang, A.; Qiu, M.; Xu, X. Genetic Evidence that Dorsal Spinal Oligodendrocyte Progenitor Cells are Capable of Myelinating Ventral Axons Effectively in Mice. Neurosci. Bull. 2020, 36, 1474-1483. [CrossRef]

24. Sommer, I.; Schachner, M. Monoclonal antibodies (O1 to O4) to oligodendrocyte cell surfaces: An immunocytological study in the central nervous system. Dev. Biol. 1981, 83, 311-327. [CrossRef]

25. Braun, P.E.; Sandillon, F.; Edwards, A.; Matthieu, J.M.; Privat, A. Immunocytochemical localization by electron microscopy of $2^{\prime} 3^{\prime}$-cyclic nucleotide $3^{\prime}$-phosphodiesterase in developing oligodendrocytes of normal and mutant brain. J. Neurosci. 1988, 8 , 3057-3066. [CrossRef] [PubMed]

26. Zhou, Q.; Anderson, D.J. The bHLH transcription factors OLIG2 and OLIG1 couple neuronal and glial subtype specification. Cell 2002, 109, 61-73. [CrossRef] 
27. Lu, Q.R.; Sun, T.; Zhu, Z.; Ma, N.; Garcia, M.; Stiles, C.D.; Rowitch, D.H. Common developmental requirement for Olig function indicates a motor neuron/oligodendrocyte connection. Cell 2002, 109, 75-86. [CrossRef]

28. Maire, C.L.; Wegener, A.; Kerninon, C.; Nait Oumesmar, B. Gain-of-function of Olig transcription factors enhances oligodendrogenesis and myelination. Stem Cells 2010, 28, 1611-1622. [CrossRef] [PubMed]

29. Lu, Q.R.; Yuk, D.; Alberta, J.A.; Zhu, Z.; Pawlitzky, I.; Chan, J.; McMahon, A.P.; Stiles, C.D.; Rowitch, D.H. Sonic hedgehogregulated oligodendrocyte lineage genes encoding bHLH proteins in the mammalian central nervous system. Neuron 2000, 25, 317-329. [CrossRef]

30. Paes de Faria, J.; Kessaris, N.; Andrew, P.; Richardson, W.D.; Li, H. New Olig1 null mice confirm a non-essential role for Olig1 in oligodendrocyte development. BMC Neurosci. 2014, 15, 12. [CrossRef] [PubMed]

31. Liu, Z.; Hu, X.; Cai, J.; Liu, B.; Peng, X.; Wegner, M.; Qiu, M. Induction of oligodendrocyte differentiation by Olig2 and Sox10: Evidence for reciprocal interactions and dosage-dependent mechanisms. Dev. Biol. 2007, 302, 683-693. [CrossRef]

32. Kuhlbrodt, K.; Herbarth, B.; Sock, E.; Hermans-Borgmeyer, I.; Wegner, M. Sox10, a novel transcriptional modulator in glial cells. J. Neurosci. 1998, 18, 237-250. [CrossRef] [PubMed]

33. Emery, B. Playing the field: Sox10 recruits different partners to drive central and peripheral myelination. PLoS Genet. 2013, 9, e1003918. [CrossRef]

34. Fauveau, M.; Wilmet, B.; Deboux, C.; Benardais, K.; Bachelin, C.; Temporao, A.C.; Kerninon, C.; Nait Oumesmar, B. SOX17 transcription factor negatively regulates oligodendrocyte precursor cell differentiation. Glia 2018, 66, 2221-2232. [CrossRef] [PubMed]

35. Chew, L.J.; Ming, X.; McEllin, B.; Dupree, J.; Hong, E.; Catron, M.; Fauveau, M.; Nait-Oumesmar, B.; Gallo, V. Sox17 Regulates a Program of Oligodendrocyte Progenitor Cell Expansion and Differentiation during Development and Repair. Cell Rep. 2019, 29, 3173-3186.e7. [CrossRef]

36. Stolt, C.C.; Schlierf, A.; Lommes, P.; Hillgartner, S.; Werner, T.; Kosian, T.; Sock, E.; Kessaris, N.; Richardson, W.D.; Lefebvre, V.; et al. SoxD proteins influence multiple stages of oligodendrocyte development and modulate SoxE protein function. Dev. Cell 2006, 11, 697-709. [CrossRef]

37. Liu, A.; Li, J.; Marin-Husstege, M.; Kageyama, R.; Fan, Y.; Gelinas, C.; Casaccia-Bonnefil, P. A molecular insight of Hes5-dependent inhibition of myelin gene expression: Old partners and new players. EMBO J. 2006, 25, 4833-4842. [CrossRef]

38. Samanta, J.; Kessler, J.A. Interactions between ID and OLIG proteins mediate the inhibitory effects of BMP4 on oligodendroglial differentiation. Development 2004, 131, 4131-4142. [CrossRef] [PubMed]

39. Meffre, D.; Shackleford, G.; Hichor, M.; Gorgievski, V.; Tzavara, E.T.; Trousson, A.; Ghoumari, A.M.; Deboux, C.; Nait Oumesmar, B.; Liere, P.; et al. Liver X receptors alpha and beta promote myelination and remyelination in the cerebellum. Proc. Natl. Acad. Sci. USA 2015, 112, 7587-7592. [CrossRef]

40. Huang, J.K.; Jarjour, A.A.; Nait Oumesmar, B.; Kerninon, C.; Williams, A.; Krezel, W.; Kagechika, H.; Bauer, J.; Zhao, C.; Baron-Van Evercooren, A.; et al. Retinoid X receptor gamma signaling accelerates CNS remyelination. Nat. Neurosci. 2011, 14, 45-53. [CrossRef]

41. de la Fuente, A.G.; Errea, O.; van Wijngaarden, P.; Gonzalez, G.A.; Kerninon, C.; Jarjour, A.A.; Lewis, H.J.; Jones, C.A.; Nait-Oumesmar, B.; Zhao, C.; et al. Vitamin D receptor-retinoid X receptor heterodimer signaling regulates oligodendrocyte progenitor cell differentiation. J. Cell Biol. 2015, 211, 975-985. [CrossRef]

42. Demerens, C.; Stankoff, B.; Logak, M.; Anglade, P.; Allinquant, B.; Couraud, F.; Zalc, B.; Lubetzki, C. Induction of myelination in the central nervous system by electrical activity. Proc. Natl. Acad. Sci. USA 1996, 93, 9887-9892. [CrossRef] [PubMed]

43. Gibson, E.M.; Purger, D.; Mount, C.W.; Goldstein, A.K.; Lin, G.L.; Wood, L.S.; Inema, I.; Miller, S.E.; Bieri, G.; Zuchero, J.B.; et al. Neuronal activity promotes oligodendrogenesis and adaptive myelination in the mammalian brain. Science 2014, 344, 1252304. [CrossRef] [PubMed]

44. Wake, H.; Lee, P.R.; Fields, R.D. Control of local protein synthesis and initial events in myelination by action potentials. Science 2011, 333, 1647-1651. [CrossRef] [PubMed]

45. Hines, J.H.; Ravanelli, A.M.; Schwindt, R.; Scott, E.K.; Appel, B. Neuronal activity biases axon selection for myelination in vivo. Nat. Neurosci. 2015, 18, 683-689. [CrossRef] [PubMed]

46. Mensch, S.; Baraban, M.; Almeida, R.; Czopka, T.; Ausborn, J.; El Manira, A.; Lyons, D.A. Synaptic vesicle release regulates myelin sheath number of individual oligodendrocytes in vivo. Nat. Neurosci. 2015, 18, 628-630. [CrossRef]

47. Bergles, D.E.; Roberts, J.D.; Somogyi, P.; Jahr, C.E. Glutamatergic synapses on oligodendrocyte precursor cells in the hippocampus. Nature 2000, 405, 187-191. [CrossRef]

48. Habermacher, C.; Angulo, M.C.; Benamer, N. Glutamate versus GABA in neuron-oligodendroglia communication. Glia 2019, 67, 2092-2106. [CrossRef]

49. Snaidero, N.; Simons, M. Myelination at a glance. J. Cell Sci. 2014, 127, 2999-3004. [CrossRef]

50. Rasband, M.N. Glial Contributions to Neural Function and Disease. Mol. Cell Proteom. 2016, 15, 355-361. [CrossRef]

51. Elbaz, B.; Popko, B. Molecular Control of Oligodendrocyte Development. Trends Neurosci. 2019, 42, 263-277. [CrossRef] [PubMed]

52. Flores, A.I.; Narayanan, S.P.; Morse, E.N.; Shick, H.E.; Yin, X.; Kidd, G.; Avila, R.L.; Kirschner, D.A.; Macklin, W.B. Constitutively active Akt induces enhanced myelination in the CNS. J. Neurosci. 2008, 28, 7174-7183. [CrossRef] [PubMed]

53. Tyler, W.A.; Gangoli, N.; Gokina, P.; Kim, H.A.; Covey, M.; Levison, S.W.; Wood, T.L. Activation of the mammalian target of rapamycin (mTOR) is essential for oligodendrocyte differentiation. J. Neurosci. 2009, 29, 6367-6378. [CrossRef] 
54. Goebbels, S.; Oltrogge, J.H.; Kemper, R.; Heilmann, I.; Bormuth, I.; Wolfer, S.; Wichert, S.P.; Mobius, W.; Liu, X.; Lappe-Siefke, C.; et al. Elevated phosphatidylinositol 3,4,5-trisphosphate in glia triggers cell-autonomous membrane wrapping and myelination. J. Neurosci. 2010, 30, 8953-8964. [CrossRef] [PubMed]

55. Ishii, A.; Furusho, M.; Bansal, R. Sustained activation of ERK1/2 MAPK in oligodendrocytes and schwann cells enhances myelin growth and stimulates oligodendrocyte progenitor expansion. J. Neurosci. 2013, 33, 175-186. [CrossRef]

56. Fancy, S.P.; Baranzini, S.E.; Zhao, C.; Yuk, D.I.; Irvine, K.A.; Kaing, S.; Sanai, N.; Franklin, R.J.; Rowitch, D.H. Dysregulation of the Wnt pathway inhibits timely myelination and remyelination in the mammalian CNS. Genes Dev. 2009, 23, 1571-1585. [CrossRef] [PubMed]

57. Piaton, G.; Gould, R.M.; Lubetzki, C. Axon-oligodendrocyte interactions during developmental myelination, demyelination and repair. J. Neurochem. 2010, 114, 1243-1260. [CrossRef]

58. Taveggia, C.; Feltri, M.L.; Wrabetz, L. Signals to promote myelin formation and repair. Nat. Rev. Neurol. 2010, 6, $276-287$. [CrossRef]

59. Camargo, N.; Goudriaan, A.; van Deijk, A.F.; Otte, W.M.; Brouwers, J.F.; Lodder, H.; Gutmann, D.H.; Nave, K.A.; Dijkhuizen, R.M.; Mansvelder, H.D.; et al. Oligodendroglial myelination requires astrocyte-derived lipids. PLoS Biol. 2017, 15, e1002605. [CrossRef]

60. Monnerie, H.; Romer, M.; Jensen, B.K.; Millar, J.S.; Jordan-Sciutto, K.L.; Kim, S.F.; Grinspan, J.B. Reduced sterol regulatory element-binding protein (SREBP) processing through site-1 protease (S1P) inhibition alters oligodendrocyte differentiation in vitro. J. Neurochem. 2017, 140, 53-67. [CrossRef]

61. Williamson, J.M.; Lyons, D.A. Myelin Dynamics Throughout Life: An Ever-Changing Landscape? Front. Cell Neurosci. 2018, 12, 424. [CrossRef] [PubMed]

62. Monje, M. Myelin Plasticity and Nervous System Function. Annu. Rev. Neurosci. 2018, 41, 61-76. [CrossRef]

63. Safaiyan, S.; Kannaiyan, N.; Snaidero, N.; Brioschi, S.; Biber, K.; Yona, S.; Edinger, A.L.; Jung, S.; Rossner, M.J.; Simons, M. Age-related myelin degradation burdens the clearance function of microglia during aging. Nat. Neurosci. 2016, 19, 995-998. [CrossRef]

64. Bergles, D.E.; Richardson, W.D. Oligodendrocyte Development and Plasticity. Cold Spring Harb. Perspect. Biol. 2015,8 , a020453. [CrossRef] [PubMed]

65. Hughes, E.G.; Orthmann-Murphy, J.L.; Langseth, A.J.; Bergles, D.E. Myelin remodeling through experience-dependent oligodendrogenesis in the adult somatosensory cortex. Nat. Neurosci. 2018, 21, 696-706. [CrossRef]

66. Vigano, F.; Mobius, W.; Gotz, M.; Dimou, L. Transplantation reveals regional differences in oligodendrocyte differentiation in the adult brain. Nat. Neurosci. 2013, 16, 1370-1372. [CrossRef] [PubMed]

67. Dimou, L.; Simons, M. Diversity of oligodendrocytes and their progenitors. Curr. Opin. Neurobiol. 2017, 47, 73-79. [CrossRef] [PubMed]

68. Swire, M.; Ffrench-Constant, C. Seeing Is Believing: Myelin Dynamics in the Adult CNS. Neuron 2018, 98, 684-686. [CrossRef] [PubMed]

69. Crawford, A.H.; Chambers, C.; Franklin, R.J. Remyelination: The true regeneration of the central nervous system. J. Comp. Pathol. 2013, 149, 242-254. [CrossRef] [PubMed]

70. Natrajan, M.S.; de la Fuente, A.G.; Crawford, A.H.; Linehan, E.; Nunez, V.; Johnson, K.R.; Wu, T.; Fitzgerald, D.C.; Ricote, M.; Bielekova, B.; et al. Retinoid X receptor activation reverses age-related deficiencies in myelin debris phagocytosis and remyelination. Brain 2015, 138, 3581-3597. [CrossRef]

71. Nakatani, H.; Martin, E.; Hassani, H.; Clavairoly, A.; Maire, C.L.; Viadieu, A.; Kerninon, C.; Delmasure, A.; Frah, M.; Weber, M.; et al. Ascl1/Mash1 promotes brain oligodendrogenesis during myelination and remyelination. J. Neurosci. 2013, 33, $9752-9768$. [CrossRef]

72. Wegener, A.; Deboux, C.; Bachelin, C.; Frah, M.; Kerninon, C.; Seilhean, D.; Weider, M.; Wegner, M.; Nait-Oumesmar, B. Gain of Olig2 function in oligodendrocyte progenitors promotes remyelination. Brain 2015, 138, 120-135. [CrossRef]

73. Arnett, H.A.; Fancy, S.P.; Alberta, J.A.; Zhao, C.; Plant, S.R.; Kaing, S.; Raine, C.S.; Rowitch, D.H.; Franklin, R.J.; Stiles, C.D. bHLH transcription factor Olig1 is required to repair demyelinated lesions in the CNS. Science 2004, 306, 2111-2115. [CrossRef]

74. Marques, S.; Zeisel, A.; Codeluppi, S.; van Bruggen, D.; Mendanha Falcao, A.; Xiao, L.; Li, H.; Haring, M.; Hochgerner, H.; Romanov, R.A.; et al. Oligodendrocyte heterogeneity in the mouse juvenile and adult central nervous system. Science 2016, 352, 1326-1329. [CrossRef]

75. Falcão, A.M.; van Bruggen, D.; Marques, S.; Meijer, M.; Jäkel, S.; Agirre, E.; Floriddia, E.M.; Vanichkina, D.P.; Williams, A.; Guerreiro-Cacais, A.O.; et al. Disease-specific oligodendrocyte lineage cells arise in multiple sclerosis. Nat. Med. 2018, 24, 1837-1844. [CrossRef]

76. Jakel, S.; Agirre, E.; Mendanha Falcao, A.; van Bruggen, D.; Lee, K.W.; Knuesel, I.; Malhotra, D.; Ffrench-Constant, C.; Williams, A.; Castelo-Branco, G. Altered human oligodendrocyte heterogeneity in multiple sclerosis. Nature 2019, 566, 543-547. [CrossRef]

77. Yeung, M.S.Y.; Djelloul, M.; Steiner, E.; Bernard, S.; Salehpour, M.; Possnert, G.; Brundin, L.; Frisen, J. Dynamics of oligodendrocyte generation in multiple sclerosis. Nature 2019, 566, 538-542. [CrossRef]

78. Kirby, L.; Jin, J.; Cardona, J.G.; Smith, M.D.; Martin, K.A.; Wang, J.; Strasburger, H.; Herbst, L.; Alexis, M.; Karnell, J.; et al. Oligodendrocyte precursor cells present antigen and are cytotoxic targets in inflammatory demyelination. Nat. Commun. 2019, 10, 3887. [CrossRef] 
79. Franklin, R.J.; Ffrench-Constant, C. Remyelination in the CNS: From biology to therapy. Nat. Rev. Neurosci. 2008, 9, 839-855. [CrossRef]

80. Franklin, R.J.; Kotter, M.R. The biology of CNS remyelination: The key to therapeutic advances. J. Neurol. 2008, 255 (Suppl. 1), 19-25. [CrossRef]

81. Lucchinetti, C.; Bruck, W.; Parisi, J.; Scheithauer, B.; Rodriguez, M.; Lassmann, H. Heterogeneity of multiple sclerosis lesions: Implications for the pathogenesis of demyelination. Ann. Neurol. 2000, 47, 707-717. [CrossRef]

82. Frischer, J.M.; Weigand, S.D.; Guo, Y.; Kale, N.; Parisi, J.E.; Pirko, I.; Mandrekar, J.; Bramow, S.; Metz, I.; Bruck, W.; et al. Clinical and pathological insights into the dynamic nature of the white matter multiple sclerosis plaque. Ann. Neurol. 2015, 78, 710-721. [CrossRef]

83. Hoftberger, R.; Lassmann, H. Inflammatory demyelinating diseases of the central nervous system. Handb. Clin. Neurol. 2017, 145, 263-283. [CrossRef]

84. Kuhlmann, T.; Miron, V.; Cui, Q.; Wegner, C.; Antel, J.; Bruck, W. Differentiation block of oligodendroglial progenitor cells as a cause for remyelination failure in chronic multiple sclerosis. Brain 2008, 131, 1749-1758. [CrossRef]

85. Tsunoda, I.; Fujinami, R.S. Inside-Out versus Outside-In models for virus induced demyelination: Axonal damage triggering demyelination. Springer Semin. Immunopathol. 2002, 24, 105-125. [CrossRef]

86. Findling, O.; Sellner, J. Second-generation immunotherapeutics in multiple sclerosis: Can we discard their precursors? Drug Discov. Today 2020, 26, 416-428. [CrossRef]

87. Mozafari, S.; Starost, L.; Manot-Saillet, B.; Garcia-Diaz, B.; Xu, Y.K.T.; Roussel, D.; Levy, M.J.F.; Ottoboni, L.; Kim, K.P.; Scholer, H.R.; et al. Multiple sclerosis iPS-derived oligodendroglia conserve their properties to functionally interact with axons and glia in vivo. Sci. Adv. 2020, 6. [CrossRef]

88. Deshmukh, V.A.; Tardif, V.; Lyssiotis, C.A.; Green, C.C.; Kerman, B.; Kim, H.J.; Padmanabhan, K.; Swoboda, J.G.; Ahmad, I.; Kondo, T.; et al. A regenerative approach to the treatment of multiple sclerosis. Nature 2013, 502, 327-332. [CrossRef]

89. Mei, F.; Fancy, S.P.J.; Shen, Y.A.; Niu, J.; Zhao, C.; Presley, B.; Miao, E.; Lee, S.; Mayoral, S.R.; Redmond, S.A.; et al. Micropillar arrays as a high-throughput screening platform for therapeutics in multiple sclerosis. Nat. Med. 2014, 20, 954-960. [CrossRef]

90. Mei, F.; Lehmann-Horn, K.; Shen, Y.A.; Rankin, K.A.; Stebbins, K.J.; Lorrain, D.S.; Pekarek, K.; Sagan, S.A.; Xiao, L.; Teuscher, C.; et al. Accelerated remyelination during inflammatory demyelination prevents axonal loss and improves functional recovery. Elife 2016, 5. [CrossRef]

91. Li, Z.; He, Y.; Fan, S.; Sun, B. Clemastine rescues behavioral changes and enhances remyelination in the cuprizone mouse model of demyelination. Neurosci. Bull. 2015, 31, 617-625. [CrossRef] [PubMed]

92. Liu, J.; Dupree, J.L.; Gacias, M.; Frawley, R.; Sikder, T.; Naik, P.; Casaccia, P. Clemastine Enhances Myelination in the Prefrontal Cortex and Rescues Behavioral Changes in Socially Isolated Mice. J. Neurosci. 2016, 36, 957-962. [CrossRef]

93. Mi, S.; Miller, R.H.; Lee, X.; Scott, M.L.; Shulag-Morskaya, S.; Shao, Z.; Chang, J.; Thill, G.; Levesque, M.; Zhang, M.; et al. LINGO-1 negatively regulates myelination by oligodendrocytes. Nat. Neurosci. 2005, 8, 745-751. [CrossRef]

94. Ruggieri, S.; Tortorella, C.; Gasperini, C. Anti lingo 1 (opicinumab) a new monoclonal antibody tested in relapsing remitting multiple sclerosis. Expert Rev. Neurother. 2017, 17, 1081-1089. [CrossRef]

95. Filbin, M.T. Myelin-associated inhibitors of axonal regeneration in the adult mammalian CNS. Nat. Rev. Neurosci. 2003, 4, 703-713. [CrossRef]

96. Cadavid, D.; Mellion, M.; Hupperts, R.; Edwards, K.R.; Calabresi, P.A.; Drulovic, J.; Giovannoni, G.; Hartung, H.P.; Arnold, D.L.; Fisher, E.; et al. Safety and efficacy of opicinumab in patients with relapsing multiple sclerosis (SYNERGY): A randomised, placebo-controlled, phase 2 trial. Lancet Neurol. 2019, 18, 845-856. [CrossRef]

97. Jarskog, L.F.; Lowy, M.T.; Grove, R.A.; Keefe, R.S.; Horrigan, J.P.; Ball, M.P.; Breier, A.; Buchanan, R.W.; Carter, C.S.; Csernansky, J.G.; et al. A Phase II study of a histamine H(3) receptor antagonist GSK239512 for cognitive impairment in stable schizophrenia subjects on antipsychotic therapy. Schizophr. Res. 2015, 164, 136-142. [CrossRef]

98. Chen, Y.; Zhen, W.; Guo, T.; Zhao, Y.; Liu, A.; Rubio, J.P.; Krull, D.; Richardson, J.C.; Lu, H.; Wang, R. Histamine Receptor 3 negatively regulates oligodendrocyte differentiation and remyelination. PLoS ONE 2017, 12, e0189380. [CrossRef]

99. Schwartzbach, C.J.; Grove, R.A.; Brown, R.; Tompson, D.; Then Bergh, F.; Arnold, D.L. Lesion remyelinating activity of GSK239512 versus placebo in patients with relapsing-remitting multiple sclerosis: A randomised, single-blind, phase II study. J. Neurol. 2017, 264, 304-315. [CrossRef]

100. Najm, F.J.; Madhavan, M.; Zaremba, A.; Shick, E.; Karl, R.T.; Factor, D.C.; Miller, T.E.; Nevin, Z.S.; Kantor, C.; Sargent, A.; et al. Drug-based modulation of endogenous stem cells promotes functional remyelination in vivo. Nature 2015, 522, 216-220. [CrossRef]

101. Hubler, Z.; Allimuthu, D.; Bederman, I.; Elitt, M.S.; Madhavan, M.; Allan, K.C.; Shick, H.E.; Garrison, E.; Karl, M.T.; Factor, D.C.; et al. Accumulation of 8,9-unsaturated sterols drives oligodendrocyte formation and remyelination. Nature 2018, 560, 372-376. [CrossRef] [PubMed]

102. Porcu, G.; Serone, E.; De Nardis, V.; Di Giandomenico, D.; Lucisano, G.; Scardapane, M.; Poma, A.; Ragnini-Wilson, A. Clobetasol and Halcinonide Act as Smoothened Agonists to Promote Myelin Gene Expression and RxRgamma Receptor Activation. PLoS ONE 2015, 10, e0144550. [CrossRef] [PubMed] 
103. Lariosa-Willingham, K.D.; Rosler, E.S.; Tung, J.S.; Dugas, J.C.; Collins, T.L.; Leonoudakis, D. A high throughput drug screening assay to identify compounds that promote oligodendrocyte differentiation using acutely dissociated and purified oligodendrocyte precursor cells. BMC Res. Notes 2016, 9, 419. [CrossRef]

104. Lariosa-Willingham, K.D.; Rosler, E.S.; Tung, J.S.; Dugas, J.C.; Collins, T.L.; Leonoudakis, D. Development of a central nervous system axonal myelination assay for high throughput screening. BMC Neurosci. 2016, 17, 16. [CrossRef] [PubMed] 